\title{
The Importance of Implantology in the Undergraduate Program and the Experience of an Institution
}

\author{
La Importancia de la Implantología en el Programa \\ de Pregrado y la Experiencia de una Institución
}

\begin{abstract}
Jean Paulo Rodolfo Ferreira*; Paula Caetano Araújo"; Marcos Tadeu Adas Saliba*; Suzely Adas Saliba Moimaz ${ }^{\text {t*t }}$ \& Cléa Adas Saliba Garbin ${ }^{*+* t *}$
\end{abstract}

FERREIRA, J. P. R.; ARAÚJo, P. C.; SALIBA, M. T. A.; MOIMAZ, S. A. S. \& GARBIN, C. A. S. The importance of implantology in the undergraduate program and the experience of an institution. Int. J. Odontostomat., 9(3):525-531, 2015.

ABSTRACT: The aim of this study was to identify the teaching discipline of Implantology in all the dental schools in Brazil and report the 9 years of experience after the induction of this material in a teaching institution. The universal sample consisted of dental schools accredited by the Federal Council of Dentistry $(n=198)$. The results were analyzed with the SPSS Statistics IBM program. It was observed that the discipline of Implantology is offered by $26.9 \%$ of the institutions in the fourth year of the undergraduate course. The format of the lessons is $83.3 \%$ theory and laboratory. It is also important to note that $2.5 \%$ of the institutions do not offer Implantology as a discipline, and in $33.3 \%$ of the cases, it appears as a mandatory subject. In order to report the experience, it was observed that the patients' quality of life increased after implantation, and $69.8 \%$ classified mastication as excellent after placement of the implant element. Thus, the format offered in the discipline of Implantology proved quite variable according to each institution. The high levels of satisfaction with dental implants and the increased demand for this procedure allowed a suggestion for a possible standardization of the discipline.

KEY WORDS: students' dental, education, higher education, dental education, dental implantation.

\section{INTRODUCTION}

Dentistry is constantly evolving in Brazil and abroad, included in these scientific and technological advances are changes in the traditional treatment plans (Rezende et al., 2007). Implantology thus appears as a reflection of this reality, because the urgency to improve the quality and quantity of life led man to hone and develop more efficient systems (Ortega-Lopes et al., 2011).

Treatment with fixed and removable partial dentures has been the traditional method for addressing the replacement of teeth in Dental education (Moghadam et al., 2012). However, in 2013, the Commission on Dental Accreditation
(2015) required the inclusion of dental implants as another treatment option for patients (Moghadam et al.). This new determination was expected due to the success of implant treatment, as demonstrated in the literature.

As a result, patients using dental implants are more satisfied with the rehabilitation when compared to patients with conventional dentures (Fonseca, 2004; Hoogstraten \& Lamers, 1987), and still found is a high level of satisfaction with treatment, with a consequent improvement in the self-image and self-confidence of patients (Albrektsson et al., 1987; Boerrigter et al., 1995a, 1995b; Wismeijer et al., 1997).

Full Professor - Implant Dentistry and Surgery Disciplines, Faculty of Dentistry, Integrated Schools of Adamantina - FAI, Adamantina, Brazil.

* Doctor Degree Candidate - Department of Infant and Social Dentistry, Faculty of Dentistry, Araçatuba Dental School, Universidade Estadual Paulista, Araçatuba, Brazil.

*** Full Professor and coordinator of Public Health Post-graduation Program, Department of Infant and Social Dentistry, Faculty of Dentistry, Araçatuba Dental School, Universidade Estadual Paulista, Araçatuba, Brazil.

**** Adjunct Professor and Vice-coordinator of Public Health Post-graduation Program, Department of Infant and Social Dentistry, Faculty of Dentistry. Araçatuba Dental School, Universidade Estadual Paulista, Araçatuba, Brazil. 
As can be observed, many researches are conducted with regard to oral implantology, assisting in the development of better prognostics and altering the profile of patients who undergo therapy (Mazzonetto et al., 2010; Nóia et al., 2009; Sandor \& Carmichel, 2008). There is a growing public awareness about how dental implants can benefit oral health, facial aesthetics and the functional recovery of teeth lost, resulting in an increased demand of patients seeking this type of treatment, as well as the need for trained professionals to perform the procedure.

Currently, surgery and rehabilitation by means of implants are also performed, mostly by specialists, however, it is clear that the implant will very soon occupy a significant part of the dental procedures performed in clinics (Mattheos et al., 2010). It is important to emphasize that dentistry is an area that demands a great amount of knowledge in health and basic sciences, requiring also that the graduate student and professional working in the area are able to assimilate new technologies and scientific discoveries (Sanz et al., 2009). And still these new features that are released in the Dental market are not immediately incorporated into the curriculum of undergraduate colleges, discrediting both the student in training, as well as the area of implantology.

There is much need for dental students to thoroughly familiarize themselves with the indication, surgical principles, restorative, early diagnosis, treatment of diseases and the maintenance of dental implants. In this sense, the discipline of Implantology becomes essential for good training and the employability of future surgeon-dentists when incorporated into the labor market, and the undergraduate course in Dentistry must provide the minimum subsidaries so that the indication of the appropriate treatment and case discussion are obtained.

It is observed that Dental education is the only tool which future surgeon-dentists have, to become quality healthcare professionals both technically and scientifically with a comprehensive look at the patient and their real needs and expectations.

Considering that professional knowledge is essential to analyze the oral health condition and recommend the best treatment, always seeking to obtain the patient's complete satisfaction, the objective of this study was to show how Implantology discipline is taught in Dental colleges, and its importance in the curriculum of the undergraduate program, and report the experience of an educational institution.

\section{MATERIAL AND METHOD}

The present cross-sectional study was approved by the Unisalesiano Ethics Committee for College Research-Salesian Auxilium Catholic University Center, process \#455/2012. A pilot of the questionnaires was done to identify a profile of the universities in driving the discipline of Implantology, as well as the experience report. Authorizations from the Directors of the Dental colleges were requested and then they were informed about the research, thus clarifying the purpose and methodology to be applied. The contact was made twice by email and once by telephone.

The analysis instrument was a structured questionnaire that used the UNESP server through the link: http:// www.foa.unesp.br/sistemas/formularios/ pesquisa_odontosocial/. A program was developed in HTML and PHP with the MySQL database, directed by the Excel program. The universal sample of this study consisted of all the Dental schools in Brazil ( $n=$ 198). The final sample consisted of 52 institutions. The institutions that have integrated research were organized based on two criteria: be accredited with the Federal Council of Dentistry and accept to participate in the research.

Closed questions were asked, via questionnaire, regarding the discipline of Implantology and professional training. They addressed issues such as: when the course is offered in the undergraduate program, form in which it is given, the amount of faculty that makes up the discipline and the relevance of the material in the institution.

The content of the questionnaire aimed to observe, in a broad and simplified manner, the format for the discipline offered in Implantology in the Dental schools of Brazil.

For the experience report, we analyzed the medical records of 96 patients seen during the 9 years of existence of the Clinic of Implantology of Integrated Adamantina Colleges (IAC), Adamantina-SP, Brazil. Of the 96 patients enrolled, 2 were deceased and 63 agreed to answer the structured instrument containing questions about satisfaction with the implanted element based on the work of Leão et al. (2009).

At the end of this study, the coordinators of the participating colleges received the research results and patients who needed some type of remedial treatment 
were referred to the IAC Implantology clinic. The descriptive statistical analysis consisted of calculating the prevalence, in percentage terms, held in the IBM SPSS StatisticsVersion 19, and the Fisher's Exact test was also performed for verification of the statistically significant differences between the responses issued by the institutions, with a significance level of $5 \%$ in the bilateral tests.

\section{RESULTS}

For the realization of this work, there was much difficulty in making the first contact with the CFO accredited Dental schools due to the lack of updated contact information, both email, phone and physical address. Thus, of the total of 198 institutions accredited by the Federal Board of Dentistry, 146 refused to participate in the research. Therefore, the final sample consisted of 52 Dental schools.

Most of the participating institutions belonged to the southeast region (48.1\%), with the highest prevalence in the state of São Paulo (34.6\%), followed by Minas Gerais (11.5\%). It is important to emphasize that $57.7 \%$ of the schools in the survey were private (Table I).

It was found that the discipline of Implantology is offered in $26.9 \%$ of the institutions, in the fourth year of the undergraduate degree course, and the format of the classes are $83.3 \%$, theory and laboratory, and $16.7 \%$, theory, laboratory and clinical. $34.6 \%$ of the colleges responded that the faculty of the discipline is formed by only 2 teachers. It is also important to note that $2.5 \%$ of the institutions do not offer Implantology as a discipline, and in $33.3 \%$ of the cases, it appears as a mandatory subject. It is worth noting that there are institutions with only two years of experience with the material and others with 16 years. In relation to the undergraduate program, the minimum duration is, on average, 4.5 years with a total workload of 4,516 hours, with a standard deviation of 456 hours (Table II).

Thus, $86 \%$ of the participants stated the importance of the presence of Implantology in the curriculum of the undergraduate program in Dentistry.

The Fisher's Exact test showed statistically significant values between the geographic region and the nature of the institutions (Table III).

When it comes to reporting the experience, the pursuit of college attendance is due to the low price $(47.6 \%)$ and confidence $(39.7 \%)$ that the patients accredited to the institution. Eighty point nine percent of the respondents considered the care as great, with $92.1 \%$ of the people were satisfied with the aesthetic that the prosthesis provided them, and $98.4 \%$ reported that the quality of life increased after the implantation.

Table I. Descriptive analysis of information provided by the participating colleges, Araçatuba, Brazil.

\begin{tabular}{llcc}
\hline Variables & Categories & $\mathbf{n}$ & $\mathbf{\%}$ \\
\hline Type of Institution & Federal & 8 & 15.4 \\
& State & 6 & 11.5 \\
& Local & 5 & 9.6 \\
& Private & 30 & 57.7 \\
& Philanthropic, Denominational or Community & 3 & 5.8 \\
\hline
\end{tabular}

Table II. Descriptive analysis of information provided by the participating colleges, Araçatuba, Brazil.

\begin{tabular}{|c|c|c|c|c|}
\hline Quantitative Variables & Mínimum & Maximum & Mean & SD \\
\hline Minimum Course Duration & 4 & 9.5 & 4.58 & 0.83 \\
\hline Total workload of Dental Course & 4000 & 6000 & 4516.62 & 456.21 \\
\hline $\mathrm{n}$ of first year students & 20 & 200 & 81.02 & 40.16 \\
\hline $\mathrm{n}$ of second year students & 9 & 200 & 75.50 & 42.79 \\
\hline $\mathrm{n}$ of third year students & 10 & 200 & 73.53 & 42.51 \\
\hline $\mathrm{n}$ of fourth year students & 30 & 150 & 69.69 & 34.61 \\
\hline $\mathrm{n}$ of fifth year students & 20 & 133 & 59.87 & 34.76 \\
\hline $\mathrm{n}$ of sixth year students & 50 & 60 & 56.67 & 5.77 \\
\hline How long has the discipline been included in the curriculum? & 2 & 16 & 6.25 & 3.21 \\
\hline
\end{tabular}


Table III. Application of the chi-square test and selected Fisher's Exact test variables Araçatuba, Brazil.

\begin{tabular}{llccccc}
\hline & \multicolumn{2}{c}{ Federal/State } & \multicolumn{2}{c}{$\begin{array}{c}\text { Municipal/Private/Philanthropic, } \\
\text { Denominational or Community }\end{array}$} & \multirow{2}{*}{ P-value } \\
\cline { 3 - 6 } & & $\mathbf{n}$ & $\%$ & $\mathbf{n}$ & $\%$ & \\
\hline Geographical & North/Center East/Northeast & 13 & 92.9 & 1 & 2.6 & \multirow{2}{*}{$<0.001^{*}$} \\
\cline { 3 - 6 } Region & Southeast/South & 1 & 7.1 & 37 & 97.4 & \\
\hline
\end{tabular}

*= Fisher's Exact Test.

It was also found that the mastication was classified as poor $(22.2 \%)$ or regular $(57.1 \%)$ before the implantation. Immediately after the implant placement, the mastication was described as excellent $(69.8 \%)$ or solid (19\%).

\section{DISCUSSION}

The fixed support or removable dental implant is considered a treatment of large margin of success, both for its users as well as the performing professionals (Adell et al., 1990; Gotfredsen \& Holm, 2000; Naert et al., 2000; Thomason et al., 2003). Thus, the success of implants has brought new perspectives and viable treatment options for partially or completely edentulous patients, profoundly changing the field of Prosthodontics (Kronstrom et al., 2008). These good results and high demands for courses in Implantology, has caused universities to offer theoretical and practical lessons to their students (Caplanis et al., 2001). However, there is a great variation in how the discipline is administered (Petropoulos et al., 2006) and many Brazilian universities still do not offer it in the curriculum of undergraduate program in Dentistry.

Initially, the present study found that most participating educational institutions were in the southeast region (48.1\%), and the states of São Paulo and Minas Gerais were the most that participated in the research. A study by Queiroz (2006) showed that the southeast region is the area with the highest concentration of graduate courses in Dentistry in the country. It is also observed that the wide range of undergraduate courses in Dentistry is due to the economic development and the purchasing power of the south and southeast regions, thus characterizing an expansion without sectorial planning.

Importantly, $57.7 \%$ of the participating institutions were private. Which corroborates with the study of Queiroz, who found that in Brazil there is a greater number of private colleges of Dentistry at the expense of Federal, State and Local Municipalities, also mentioning that the addition of new courses in Dentistry in the past decade is given significantly more in private colleges. The Fisher's Exact test showed statistically significant values between the geographic region and the type of institutions $(p<0.005)$ in this study.

It was also identified that the discipline of Implantology was offered in $26.9 \%$ of the institutions, in the fourth year of the undergraduate degree course, and the format of the classes are $83.3 \%$, theory and laboratory, and $16.7 \%$, theory, laboratory and clinical. Corroborating with this evidence, studies by Lim et al. (2005) and Petropoulos et al., showed that most U.S. universities, have included both the theory and laboratory instruction execution of dental implants in their curriculums, and some universities also offer specific programs to deepen knowledge of the discipline of Implantology (Maalhagh-Fard et al., 2002). One study showed that surgeon-dentists who received theory and/or practice of Implantology courses during the Dentistry course tend to include more frequent treatments with implants in clinical practice (Huebner, 2002).

With regards to the faculty of the discipline, it was observed that $34.6 \%$ of the colleges responded that it was made up of only 2 teachers. Thus suggesting neglect and less worth with the discipline during the undergraduate degree, and instead of enhancing a commercial vision that many educational institutions have in Dentistry, urging the need for executing courses for improvement or specialization, to achieve a basic knowledge that should be provided by every institution of undergraduate education. It is worth mentioning that this study found that $2.5 \%$ of the institutions have not yet offered Implantology as a discipline, and in $33.3 \%$ of the cases, it appears as a mandatory subject, where the minimum duration of the course is on average of 4.5 years and the total workload amounts to 4,516 hours. A fact that agrees with studies conducted in the United States by Caplanis et al., who mentioned that many American universities have been offering the course for undergraduate students. 
It has also shown that $86 \%$ of the participants have stated the importance of the existence of Implantology in the curriculum of the undergraduate course in Dentistry.

It is noted, therefore, that much is needed for the improvement for building a more appropriate profile for the professional. The negative evaluation of both the teaching and the curriculum in the health area brought the affirmation of the Law of Guidelines and Bases (LGB) (Senado do República Federativa do Brasil, 1996) and the National Curriculum Guidelines (NCG) for health courses (Ministério da Saúde, 2002). The entirety of actions becomes the focus of conduct and procedures in order to objectify the social relevance and technical skill, opposing the biomedical model (Feuerwerker \& Sena, 2002).

In what pertains to the experience report, it can be observed that the search for service in the college is due to the low price (47.6\%) and confidence (39.7\%) that the patients instill in the institution. Eighty point nine percent of the respondents consider it as great care, while $92.1 \%$ of the people are satisfied with the aesthetics of the prosthesis that the implant provides. It was also found that the mastication was classified as poor $(22.2 \%)$ or regular (57.1\%) before implantation. Immediately after the implant element placement, the mastication was described as excellent $(69.8 \%)$ or good $(19 \%)$, and these data corroborate with the study of Leão et al. It is worth noting that $98.4 \%$ of the participants reported an increase in the quality of life after implantation.

It was thus noted that teaching applied to Implantology is of great benefit for the community, giving community members a better quality of life and well-being. With respect to the training of undergraduate students, this course provides not only the knowledge to perform the technical execution and maintenance of the implant element, but also shows the deep integration of oral health with the systemic health for successful procedures and patient satisfaction (Lim et al.).

It is concluded through this study that in most colleges, the discipline of Implantology is taught in the final year of the undergraduate degree course, and the theoretical lessons are the most frequent. The faculty consists of a few teachers, and there are still universities in Brazil who offer the discipline as not mandatory. And still most participants believe that the discipline is very important for the proper formation of majoring in Dentistry. As for the experience report, the study has found that most of its patients have sought the colleges because of cost and confidence in the institution, ranking the service as great. The vast majority of patients seen are satisfied with both the aesthetics, as well as the function of the implants, exponentially increasing the quality of life of these individuals. A possible standardization and enhancement of the area between the educational institutions is therefore suggested so that students have a better academic formation, and the community is more broadly served, hence benefiting from treatment.

\section{ACKNOWLEDGEMENTS}

This study was supported by grants of CAPES Foundation (Coordination for the Improvement of Higher Education Personnel) through a doctor degree scholarship.

FERREIRA, J. P. R.; ARAÚJO, P. C.; SALIBA, M. T. A.; MOIMAZ, S. A. S. \& GARBIN, C. A. S. La importancia de la Implantología en el programa de pregrado y la experiencia de una institución. Int. J. Odontostomat., 9(3):525-531, 2015.

RESUMEN: El objetivo fue identificar la enseñanza de la disciplina de Implantología en todas las escuelas de odontología en Brasil y reportar los 9 años de experiencia después del inicio de esta disciplina en una institución. La muestra consistió en escuelas de odontologia acreditadas por el Consejo Federal de Odontología $(n=198)$. Los resultados fueron analizados con el paquete estadístico SPSS IBM. La disciplina de Implantología es ofrecida por el $26,9 \%$ de las instituciones en el cuarto año del pregrado en Odontología. El formato de clases fue teórico y práctico $(83,3 \%)$. En 2,5\% de las instituciones no se ofrece Implantología como disciplina, y en $33,3 \%$ de los casos, aparece como una disciplina obligatoria. Con el fin de informar la experiencia de una institución, se observó que la calidad de vida de los pacientes aumentó después de la colocación de implantes y $69,8 \%$ clasificaron su masticación como excelente después de la colocación de implantes. El formato que se ofrece en la disciplina de Implantología se mostró muy variable en cada institución. Los altos niveles de satisfacción con los implantes dentales y el aumento de la demanda de este procedimiento permite una sugerir una posible normalización de la disciplina.

PALABRAS CLAVE: estudiantes de odontologia, educación superior, educación en odontologia, implantología. 


\section{REFERENCES}

Adell, R.; Eriksson, B.; Lekholm, U.; Brånemark, P. I. \& Jemt, T. Long-term follow-up study of osseointegrated implants in the treatment of totally edentulous jaws. Int. J. Oral Maxillofac. Implants, 5(4):347-59, 1990.

Albrektsson, T.; Blomberg, S.; Branemark, A. \& Carlsson, G. E. Edentulousness--an oral handicap. Patient reactions to treatment with jawbone-anchored prostheses. J. Oral Rehabil., 14(6):503-11, 1987.

Boerrigter, E. M.; Geertman, M. E.; Van Oort, R. P.; Bouma, J.; Raghoebar, G. M.; van Waas, M. A.; van't Hof, M. A.; Boering, G. \& Kalk, W. Patient satisfaction with implantretained mandibular overdentures. A comparison with new complete dentures not retained by implants--a multicentre randomized clinical trial. Br. J. Oral Maxillofac. Surg., 33(5):282-8, 1995a.

Boerrigter, E. M.; Stegenga, B.; Raghoebar, G. M. \& Boering, G. Patient satisfaction and chewing ability with implantretained mandibular overdentures: a comparison with new complete dentures with or without preprosthetic surgery. J. Oral Maxillofac. Surg., 53(10):1167-73, 1995b.

Caplanis, N.; Kan, J. Y. \& Lozada, J. L. Implant dentistry education for the practicing dentist. J. Calif. Dent. Assoc., 29(11):757-64, 2001.

Commission on Dental Accreditation. Current Accreditation Standards. Chicago: American Dental Association, 2015. Available from: http://www.ada.org/en/coda/currentaccreditation-standards/

Feuerwerker, L. C. M. \& Sena, R. R. A contribution to the movement for change in professional healthcare education: an assessment of the UNI experiences. Interface (Botucatu), 6(10):37-49, 2002.

Fonseca, G. M. Grau de satisfação dos pacientes tratados com overdentures. M.S. Thesis. Rio de Janeiro, Universidade do Grande Rio, 2004.

Gotfredsen, K. \& Holm, B. Implant-supported mandibular overdentures retained with ball or bar attachments: a randomized prospective 5-year study. Int. J. Prosthodont., 13(2):125-30, 2000.

Hoogstraten, J. \& Lamers, L. M. Patient satisfaction after insertion of an osseointegrated implant bridge. J. Oral Rehabil., 14(5):481-7, 1987.

Huebner, G. R. Evaluation of a predoctoral implant curriculum: does such a program influence graduates' practice patterns? Int. J. Oral Maxillofac. Implants, 17(4):543-9, 2002.
Kronstrom, M.; McGrath, L. \& Chaytor, D. Implant dentistry in the undergraduate dental education program at Dalhousie University. Part 1: clinical outcomes. Int. J. Prosthodont., 21(2):124-8, 2008.

Leão, M. P.; Granato, R.; Oderich, E.; Boff, L. L.; Buttendorf, A. R. \& Bianchini, M. A. Avaliação da satisfação de pacientes reabilitados por implantes osseointegráveis. Implant News, 6(4):417-21, 2009.

Lim, M. V. C.; Afsharzand, Z.; Rashedi, B. \& Petropoulos, V. C. Predoctoral implant education in U.S. dental schools. J. Prosthodont., 14(1):46-56, 2005.

Maalhagh-Fard, A.; Nimmo, A.; Lepczyk, J. W. \& Pink, F. E. Implant dentistry in predoctoral education: the elective approach. J. Prosthodont., 11(3):202-7, 2002.

Mattheos, N.; Ivanovski, S.; Sambrook, P. \& Klineberg, I. Implant dentistry in Australian undergraduate dental curricula: knowledge and competencies for the graduating dentist. Aust. Dent. J., 55(3):333-8, 2010.

Mazzonetto, R.; Lopes, R. O.; Nóia, C. F. \& Chaves-Netto, H. D. N. Pesquisa básica em implantodontia. Implant News, 7(3):83-92, 2010.

Ministério da Saúde. Resolução CNE/CNS N³/2002: Institui as Diretrizes Curriculares Nacionais do Curso de Graduação em Odontologia. Brasília, Diário Oficial da União, 2002.

Moghadam, M.; Dias, R.; Kuyinu, E.; Ferguson, M. B.; Mucciolo, T. \& Jahangiri, L. Predoctoral fixed implant patient satisfaction outcome and challenges of a clinical implant competency. J. Dent. Educ., 76(4):437-42, 2012.

Naert, I.; Koutsikakis, G.; Duyck, J.; Quirynen, M.; Jacobs, R. \& van Steenberghe, D. Biologic outcome of singleimplant restorations as tooth replacements: a long-term follow-up study. Clin. Implant Dent. Relat. Res., 2(4):209-18, 2000.

Nóia, C. F.; Chaves Netto, H. D. M.; Lopes, R. O.; Rodríguez-Chessa, J. \& Mazzonetto, R. Uso de enxerto ósseo autógeno nas reconstruções da cavidade bucal. Análise retrospectiva de 07 anos. Rev. Port. Estomatol. Med. Dent. Cir. Maxilofac., 50(4):221-5, 2009.

Ortega-Lopes, R.; Nóia, C. F.; Andrade, V. C.; Cidade, C. P. V. \& Mazzonetto, R. Perfil dos pacientes tratados com implantes dentários: análise retrospectiva de sete anos. Rev. Port. Estomatol. Med. Dent. Cir. Maxilofac., 52(3):147-52, 2011. 
FERREIRA, J. P. R.; ARAÚJO, P. C.; SALIBA, M. T. A.; MOIMAZ, S. A. S. \& GARBIN, C. A. S. The importance of implantology in the undergraduate program and the experience of an institution. Int. J. Odontostomat., 9(3):525-531, 2015

Petropoulos, V. C.; Arbree, N. S.; Tarnow, D.; Rethman, M.; Malmquist, J.; Valachovic, R.; Brunson, W. D. \& Alfano, M. C. Teaching implant dentistry in the predoctoral curriculum: a report from the ADEA Implant Workshop's survey of deans. J. Dent. Educ., 70(5):580-8, 2006.

Queiroz, M. G. O ensino da odontologia no Brasil: concepções e agentes. M.S. Thesis. Goiânia, Universidade Federal de Goiás, 2006.

Rezende, F. P.; Nakanishi, F. C.; Machado, A. C. P.; Quirino, M. R. S. \& Anbinder, A. L. Perfil, motivações e expectativas dos graduandos e graduados em odontologia. Rev. Odontol. Univ. Cid. São Paulo, 19(2):165-72, 2007.

Sándor, G. K. \& Carmichel, R. P. Dental implants in children, adolescents, and young adults. Preface. Atlas Oral Maxillofac. Surg. Clin. North Am., 16(1):7-8, 2008.

Sanz, M.; Saphira, L. \& 1st European Consensus Workshop in Implant Dentistry University Education. Competencies in implant therapy for the dental graduate: appropriate educational methods. Eur. J. Dent. Educ., 13(Suppl. 1):37-43, 2009.

Senado do República Federativa do Brasil. Lei No 9394, de 20 de dezembro de 1996. Institui a lei de diretrizes e bases da educação nacional. Brasília, Diário Oficial da União, 1996.

Thomason, J. M.; Lund, J. P.; Chehade, A. \& Feine, J. S. Patient satisfaction with mandibular implant overdentures and conventional dentures 6 months after delivery. Int. J. Prosthodont., 16(5):467-73, 2003.

Wismeijer, D.; Van Waas, M. A.; Vermeeren, J. I.; Mulder, J. \& Kalk, W. Patient satisfaction with implant-supported mandibular overdentures. A comparison of three treatment strategies with ITI-dental implants. Int. J. Oral Maxillofac. Surg., 26(4):263-7, 1997.
Dirección para Correspondencia:

Cléa Adas Saliba Garbín

Departamento de Odontología Infantil y Social

Calle José Bonifácio, 1193. Villa Mendonça

CP: $16015-050$

Araçatuba - SP

BRASIL

Email: cgarbin@foa.unesp.br, paulinhacaetano@hotmail.com

Recibido : 23-06-2015

Aceptado: 28-10-2015 